\title{
Knowledge, Attitudes, and Practices of Self-ear Cleaning in Makkah Region, Cross- sectional Study
}

\author{
Aseel K. Haji ${ }^{1}$, Bashaer A. Alharbi ${ }^{1}$, Khalid A. Alhazmi ${ }^{1}$, Bassam T. Alharthi ${ }^{1}$, Abdulrahman F. Kabli ${ }^{1}$, \\ Muhammad I. Siddiqui ${ }^{2}$. \\ ${ }^{1}$ College of Medicine, Umm Al-Qura University - Makkah, Kingdom of Saudi Arabia. \\ ${ }^{2}$ Department of Community Medicine, Umm Al-Qura University, Makkah, Kingdom of Saudi Arabia.
}

\begin{abstract} health care workers and who had previous ears, nose, and throat injuries. their ear hygiene.

Keyword: Knowledge, Attitude, Practice, Self-ear Cleaning, Ear wax.

\section{Introduction}

Cerumen or ear wax is a normal secretion from sebaceous and ceruminous glands found in the external auditory canal. Cerumen protects the external auditory canal's skin via maintaining high acidic $\mathrm{pH}$ between 5.2-7, which is unfavorable for organisms and helps reduce infection risk. It also has a lubricating effect on the canal [1-3]. It moves typically outward through a self-cleaning mechanism known as the conveyor belt process of epithelial migration and does not need to be cleaned; this movement is aided by mandible movement during chewing.
\end{abstract}

Background and aim: Cerumen or ear wax is a normal secretion from sebaceous and ceruminous glands found in the external auditory canal. Wrong self-ear cleaning attempts may lead to cerumen impaction, injuries, and otitis externa. we have concluded this study to assess the local community's knowledge about ear-cleaning, attitudes toward ear care, and self-ear cleaning practices.

Methods: Cross-sectional online survey performed in May 2021 among general population to assess knowledge, attitudes, and practices of self-ear cleaning. We included all people aged between 18 to 90 years who live in Makkah region, also we excluded

Results: A total of 544 participants responded to the survey, 351 (64.5\%) were males and $193(35.5 \%)$ were females, age between 18 to 55. Forty-four (8.1\%) of participants thought that it is harmful to self-clean your ear. In contrast, 274 (50.4\%) thought that we do not have to remove the wax from our ears constantly. About $32 \%$ of them clean to remove the dirt and $29.30 \%$ clean to improve

Conclusion: Self-ear cleaning is a widespread practice, and most respondents showed a lack of knowledge regarding ear-cleansing mechanisms. In order to rectify the erroneous views, more public health education is needed to dissuade people from practicing selfear cleaning and teach them about the function of cerumen and problems associated with self-ear cleaning.

\begin{tabular}{|l|l|}
\hline \multicolumn{2}{|c|}{ Access this article online } \\
\hline Quick Response Code: & Website: \\
& www.smh-j.com \\
\cline { 2 - 2 } & DOI: \\
\hline
\end{tabular}

By this process, the canal's cerumen is moved outward along with dirt, dust, and particulate matter within the ear canal [4].Self-ear cleaning is defined as the act of inserting different objects into the ear to remove earwax. Unfortunately, it is a standard general practice that can compromise the integrity of the ear as a natural, self-cleaning mechanism [5,6]. Wrong selfear cleaning attempts may lead to cerumen impaction, injuries, and otitis externa. Cerumen impaction is described as an accumulation of cerumen resulting in symptoms or inability to assess the ear canal or

Address for correspondence: Aseel K. Haji, College of Medicine, Umm Al-Qura University - Makkah, Kingdom of Saudi Arabia

E-mail: aselkhaji@gmail.com

Received: 2 November 2021 | Accepted: 22 November 2021

This is an open access article by SMHJ is licensed under Creative Commons Attribution 4.0 International License.

(https://creativecommons.org/licenses/by/4.0)

Please cite this article as: Haji A, Alharbi B, Alhazmi K, Alharthi B, Kabli A, Siddiqui MI. The Knowledge, Attitudes, and Practices of Self-ear Cleaning in Makkah Region, Cross-sectional Study: Self-ear Cleaning . SMHJ [Internet]. 2021;1(1): 2633.

(C) Saudi Medical Horizons Journal

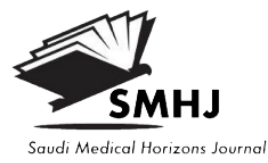


tympanic membrane [7-9]. Cerumen impaction is present in up to $6 \%$ of the population [10], and the most common otolaryngology procedure performed in primary care is cerumen removal [11]. Cotton buds are considered one of the most preferred objects used for self-ear cleaning, and some people use a finger, biro pen cover, feather, broomstick, and matchstick [1]. We believe that with good education to the community and more efforts to raise public awareness about the suitable options for ear-cleaning and the possible complications of these unprofessional practices, we will have some improvement at the level of public awareness. Therefore, we have conducted this study to assess the local community's knowledge about ear cleaning, attitudes toward ear care, and self-ear cleaning practices.

\section{Methods}

A cross-sectional online survey performed in May 2021 among general population to assess knowledge, attitudes, and practices of self-ear cleaning. Sampling technique used in this study was convenience sampling technique to select the participants. We included all people aged between 18 to 90 years who live in Makkah region, also we excluded health care workers and who had previous ears, nose, and throat injuries. We used software Epiinfo version 3.0 to calculate the accurate size considering the population size in Makkah regions which is about 8.8 million inhabitants. The confidence interval (CI) level at 95\%, and the anticipated $\%$ of frequency considered as $50 \%$. Sample size was calculated to be 385 participants. In case of data loss, a total sample size of 400 participants was required. However, in our study we included 546 participants. Our survey was conducted after reviewing previously published studies and developed by the author. Our survey was conducted online and designed by Google forms (R), then it was distributed electronically via social media apps. The questionnaire covered the demographical data of the participants, questions regarding the knowledge, practice of self-ear cleaning and attitudes of self-ear cleaning. To assess the level of knowledge participants needed to get more than $60 \%$ of the answers right, each right answer was given a score of one, participant who got 4 or more considered having good knowledge. The language of the survey was translated to Arabic and then, it was translated back to English for analysis and publication. We used Statistical Package for the Social Sciences (SPSS) version 23 to do the data analysis of the study. Absolute frequencies and percentages were used to describe the categorical variables. Chi-square tests were used to compare the proportion of categorical data. Also, a student t-test of independence was performed to compare the numerical data of the study. Statistical significance was set at $\mathrm{P}<0.05$ and CI was set at $95 \%$.

The study was approved by the Ethics and Research Review Committee of Umm Al-Qura University, Faculty of Medicine (Approval number: HAPO-02-K012-2021-4-673), Date of approval was on 25/4/2021.

\section{Results}

A total of 544 participants responded to the survey, $351(64.5 \%)$ were males and $193(35.5 \%)$ were females. The age of participants was between 18 to 55 with a mean of 23.4. Most of the responses were from Makkah city with 264 (48.5\%) followed by Jeddah city with 208 (38.2\%). Regarding the educational level of participants, most of them have a university degree with $440(80.9 \%)$ and only $3(0.3 \%)$ participants who only had primary school degrees. When we asked about the income of the participants, 354 (65.1\%) of them had an income of less than 1 thousand Saudi Riyal. Regarding practicing self-ear cleaning, 389 (71.5\%) participants practice self-ear cleaning (Table1). Out of 544 participants 109 (20\%) scored more than $60 \%$ which was considered the base line of good knowledge (Figure1). To assess the level of knowledge of participants toward self-ear cleaning, we have asked multiple questions and the data revealed that only $44(8.1 \%)$ of participant thought that it is harmful to self-clean your ear. While 274 (50.4\%) thought that we do not have to remove the wax from our ears constantly. Regarding, surgery if the ear drum rupture $223(41.0 \%)$ thought it is not necessary to do the surgery, around $478(87.9 \%)$ responded that high pitch sound can damage hearing (Table2). When participants were asked about the reason of performing self-ear cleaning $31.60 \%$ of them clean to remove the dirt and $29.30 \%$ clean to improve their ear hygiene (Figure2). $31.10 \%$ of the participant clean their ear once a week, and $66 \%$ of participants who clean their ear they use cotton bud (Table 3). Out of the 389 participant who practice self-ear cleaning 381 (97.9\%) clean both ears, $70(18.0 \%)$ of them had itching after cleaning their ears and $249(64.0 \%)$ did not have any symptoms. $13(3.3 \%)$ had otitis externa as a complication after cleaning their ears (Table3). Participants also were asked about their attitude regarding self-ear cleaning, $370(68.1 \%)$ of them believe that they will consult a doctor if they experience pain in the ear, however 49 (9\%) will use herbals if pain occurs. Participants who do not practice self-ear cleaning were asked for the reason they avoid it, $67(12.3 \%)$ answers due to the fear of having wax 
impaction as a consequence (Table 4).The next section of the survey was concerning the association between knowledge and demographic factors, the result showed that the gender was significant to the knowledge of self-ear cleaning, however the age, city, education, and income had no significant association with the knowledge (Table 5). Relationship between practice of self-ear cleaning and demographic factors was also analysed, no significant value was found between practicing self-ear cleaning and age, education, income. Nevertheless, significant value was found between city and gender when linked with practicing self-ear cleaning (Table 6).

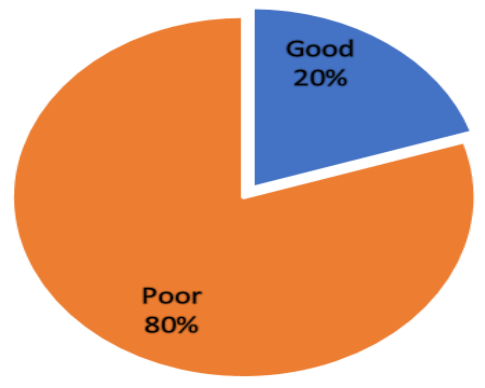

Figure 1 Level of knowledge of self-ear cleaning and it is complication.

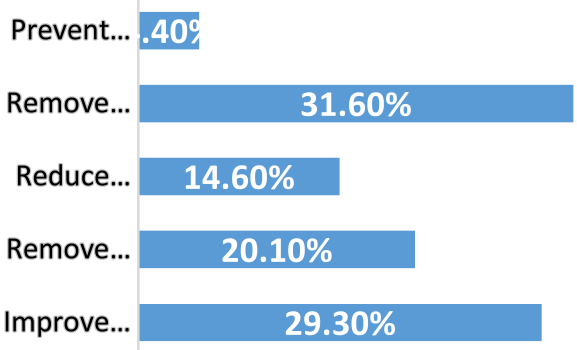

Figure 2 Distribution of reason of cleaning of ear as described by participants.

Table 1: Demographic data.

\begin{tabular}{|c|c|c|}
\hline Variable & Category & $\begin{array}{c}\text { Frequency } \\
(\%)\end{array}$ \\
\hline $\begin{array}{c}\text { Age } \\
\text { (years)mean, } \\
S D(\text { median } \\
[I Q R])\end{array}$ & $23.4,6.22(22[20-24])$ \\
\hline Age & $18-24$ & $412(75.7 \%)$ \\
\cline { 2 - 3 } & $25-30$ & $89(16.4 \%)$ \\
\hline
\end{tabular}

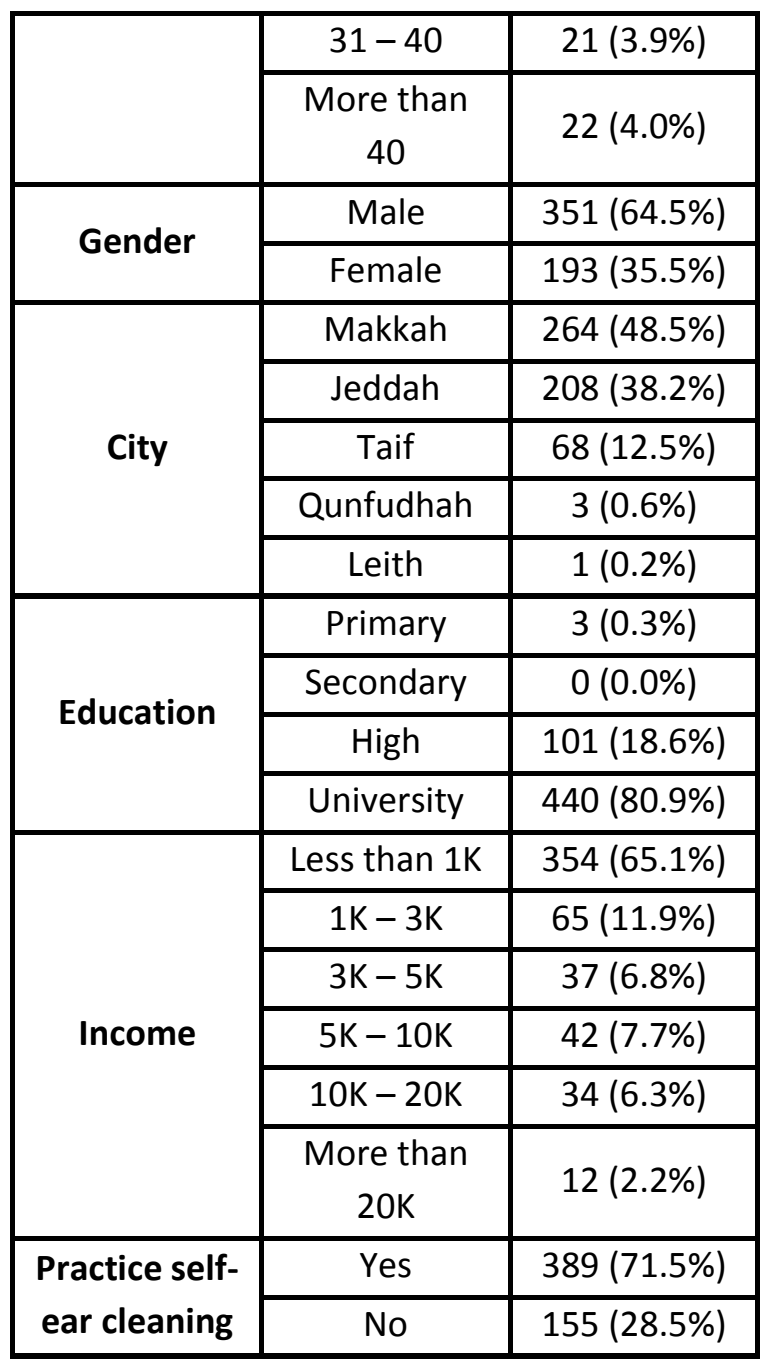

Table 2: Knowledge regarding self-ear cleaning.

\begin{tabular}{|c|c|c|}
\hline Questions & Frequency & (\%) \\
\hline \multicolumn{3}{|c|}{ What do you think of self-ear cleaning? } \\
\hline Beneficial & 238 & 43.8 \\
\hline $\begin{array}{c}\text { Non- } \\
\text { beneficial }\end{array}$ & 26 & 4.8 \\
\hline Harmful * & 44 & 8.1 \\
\hline Not sure & 236 & 43.4 \\
\hline \multicolumn{3}{|c|}{ Do I have to remove ear wax constantly? } \\
\hline Yes & 270 & 49.6 \\
\hline No ${ }^{*}$ & 274 & 50.4 \\
\hline \multicolumn{3}{|c|}{ Rupture ear drum needs surgery? } \\
\hline Yes * & 321 & 59.0 \\
\hline No & 223 & 41.0 \\
\hline
\end{tabular}




\begin{tabular}{|c|c|c|}
\hline \multicolumn{3}{|c|}{$\begin{array}{l}\text { High pitch sound can cause damage to your } \\
\text { hearing? }\end{array}$} \\
\hline Yes* & 478 & 87.9 \\
\hline No & 66 & 12.1 \\
\hline \multicolumn{3}{|c|}{$\begin{array}{l}\text { I need to consult a doctor if I have hearing } \\
\text { difficulty? }\end{array}$} \\
\hline Yes* & 215 & 39.5 \\
\hline No & 329 & 60.5 \\
\hline \multicolumn{3}{|c|}{ High and low attitude can cause earache? } \\
\hline Yes $*$ & 467 & 85.8 \\
\hline No & 77 & 14.2 \\
\hline
\end{tabular}

Table 3: Practice of self-ear cleaning.

\begin{tabular}{|c|c|c|}
\hline $\begin{array}{c}\text { Characteristics } \\
\text { of Ear } \\
\text { cleaning }\end{array}$ & Frequency & (\%) \\
\hline \multicolumn{3}{|c|}{ Which ear do you clean? } \\
\hline Both & 381 & 97.9 \\
\hline Right & 5 & 1.3 \\
\hline Left & 3 & 0.8 \\
\hline \multicolumn{3}{|c|}{ What tools do you use for self-ear cleaning? } \\
\hline Cotton bed & 326 & 66.1 \\
\hline Fingers & 96 & 19.5 \\
\hline Tissues & 45 & 9.1 \\
\hline Keys & 13 & 2.6 \\
\hline Others & 13 & 2.6 \\
\hline \multicolumn{3}{|c|}{$\begin{array}{l}\text { What symptoms did you have after cleaning } \\
\text { your ear? }\end{array}$} \\
\hline Itching & 70 & 18.0 \\
\hline Pain & 31 & 8.0 \\
\hline Discharges & 17 & 4.4 \\
\hline Fullness & 9 & 2.3 \\
\hline Dizziness & 2 & 0.5 \\
\hline $\begin{array}{l}\text { Difficulty } \\
\text { hearing }\end{array}$ & 11 & 2.8 \\
\hline None & 249 & 64.0 \\
\hline \multicolumn{3}{|c|}{$\begin{array}{l}\text { How frequent do you practice self-ear } \\
\text { cleaning? }\end{array}$} \\
\hline Once a day & 95 & 17.5 \\
\hline
\end{tabular}

\begin{tabular}{|c|c|c|}
\hline $\begin{array}{l}\text { More than } \\
\text { once a day }\end{array}$ & 34 & 6.3 \\
\hline Once a week & 121 & 22.2 \\
\hline $\begin{array}{c}\text { More than } \\
\text { once a week }\end{array}$ & 95 & 17.5 \\
\hline Monthly & 44 & 8.1 \\
\hline \multicolumn{3}{|c|}{ Since when you use cotton to clean your ea } \\
\hline $\begin{array}{l}\text { Less than } 5 \\
\text { years }\end{array}$ & 68 & 17.5 \\
\hline $\begin{array}{c}\text { more than } 5 \\
\text { years }\end{array}$ & 259 & 66.6 \\
\hline $\begin{array}{l}\text { I do not use } \\
\text { cotton buds }\end{array}$ & 62 & 16.0 \\
\hline \multicolumn{3}{|c|}{$\begin{array}{l}\text { Complications you have experienced after } \\
\text { ear cleaning }\end{array}$} \\
\hline Otitis externa & 13 & 3.3 \\
\hline Pain & 38 & 9.5 \\
\hline Bleed & 5 & 1.3 \\
\hline None & 342 & 85.9 \\
\hline
\end{tabular}

Table 4: Attitude of participants regarding selfear cleaning.

\begin{tabular}{|c|c|c|}
\hline Questions & Frequency & (\%) \\
\hline $\begin{array}{c}\text { What are the reasons that make you avoid } \\
\text { self-ear cleaning? }\end{array}$ \\
\hline Use herbal & 49 & 9 \\
\hline $\begin{array}{c}\text { Consult a } \\
\text { doctor }\end{array}$ & 370 & 68.1 \\
\hline $\begin{array}{c}\text { Use over the } \\
\text { counter } \\
\text { medications }\end{array}$ & 125 & 23 \\
\hline $\begin{array}{c}\text { What would you do if you experience ear } \\
\text { pain \& discharge? }\end{array}$ & 10.3 \\
\hline Foreign body & 56 & 5.9 \\
\hline $\begin{array}{c}\text { Infection } \\
\text { Wax } \\
\text { impaction }\end{array}$ & 32 & 12.3 \\
\hline $\begin{array}{c}\text { Not } \\
\text { applicable }\end{array}$ & 389 & 71.5 \\
\hline
\end{tabular}


Table 5: Association between knowledge and demographic data.

\begin{tabular}{|c|c|c|c|}
\hline \multirow[t]{2}{*}{ Variable } & \multicolumn{2}{|c|}{$\begin{array}{l}\text { Knowledge of self- } \\
\text { ear cleaning }\end{array}$} & \multirow[t]{2}{*}{ P VALUE } \\
\hline & Good (\%) & Poor (\%) & \\
\hline \multicolumn{4}{|l|}{ Age } \\
\hline $\begin{array}{c}\text { Less than } \\
30\end{array}$ & $\begin{array}{c}101 \\
(20.2 \%)\end{array}$ & $\begin{array}{c}400 \\
(79.8 \%)\end{array}$ & \multirow{3}{*}{0.764} \\
\hline $30-40$ & $\begin{array}{c}3 \\
(14.3 \%)\end{array}$ & $\begin{array}{c}18 \\
(85.7 \%)\end{array}$ & \\
\hline $\begin{array}{l}41 \text { and } \\
\text { above }\end{array}$ & $\begin{array}{c}5 \\
(22.7 \%)\end{array}$ & $\begin{array}{c}17 \\
(77.3 \%)\end{array}$ & \\
\hline \multicolumn{4}{|l|}{ Gender } \\
\hline Male & $\begin{array}{c}59 \\
(16.8 \%)\end{array}$ & $\begin{array}{c}292 \\
(83.2 \%)\end{array}$ & \multirow{2}{*}{$0.014 \mathrm{~F}$} \\
\hline Female & $\begin{array}{c}50 \\
(25.9 \%)\end{array}$ & $\begin{array}{c}143 \\
(74.1 \%)\end{array}$ & \\
\hline \multicolumn{4}{|l|}{ City } \\
\hline Makkah & $\begin{array}{c}50 \\
(18.9 \%)\end{array}$ & $\begin{array}{c}214 \\
(81.1 \%)\end{array}$ & \multirow{3}{*}{0.823} \\
\hline Jeddah & $\begin{array}{c}44(21.2 \\
\%)\end{array}$ & $\begin{array}{c}164 \\
(78.8 \%)\end{array}$ & \\
\hline $\begin{array}{l}\text { Taif and } \\
\text { others }\end{array}$ & $\begin{array}{c}15 \\
(20.8 \%)\end{array}$ & $\begin{array}{c}57 \\
(79.2 \%)\end{array}$ & \\
\hline \multicolumn{4}{|l|}{ Education } \\
\hline Primary & $\begin{array}{c}1 \\
(33.3 \%)\end{array}$ & $2(66.7 \%)$ & \multirow{3}{*}{0.846} \\
\hline high & $\begin{array}{c}20 \\
(19.8 \%)\end{array}$ & $\begin{array}{c}81 \\
(80.2 \%)\end{array}$ & \\
\hline University & $\begin{array}{c}88 \\
(20.0 \%)\end{array}$ & $\begin{array}{c}352 \\
(80.0 \%)\end{array}$ & \\
\hline \multicolumn{4}{|l|}{ Income } \\
\hline $\begin{array}{c}\text { Less than } \\
3 \mathrm{~K}\end{array}$ & $\begin{array}{c}87 \\
(20.8 \%)\end{array}$ & $\begin{array}{c}332 \\
(79.2 \%)\end{array}$ & \multirow{3}{*}{0.275} \\
\hline $3-5$ & $3(8.1 \%)$ & $\begin{array}{c}34 \\
(91.9 \%)\end{array}$ & \\
\hline $5-10$ & $\begin{array}{c}8 \\
(19.0 \%)\end{array}$ & $\begin{array}{c}34 \\
(81.0 \%)\end{array}$ & \\
\hline
\end{tabular}

\begin{tabular}{|c|c|c|c|}
\hline $\begin{array}{c}\text { More } \\
\text { than } 10\end{array}$ & $\begin{array}{c}11 \\
(23.9 \%)\end{array}$ & $\begin{array}{c}35 \\
(76.1 \%)\end{array}$ & \\
\hline
\end{tabular}

Table 6: Association between practice of selfear cleaning and demographic data.

\begin{tabular}{|c|c|c|c|}
\hline \multirow[t]{2}{*}{ Variable } & \multicolumn{2}{|c|}{$\begin{array}{l}\text { Practice self-ear } \\
\text { cleaning }\end{array}$} & \multirow[t]{2}{*}{$\begin{array}{l}\text { P } \\
\text { VALUE }\end{array}$} \\
\hline & Yes (\%) & No (\%) & \\
\hline \multicolumn{4}{|l|}{ Age } \\
\hline $\begin{array}{l}\text { Less than } \\
20\end{array}$ & $\begin{array}{c}296 \\
(71.8 \%)\end{array}$ & $\begin{array}{c}116 \\
(28.2 \%)\end{array}$ & \multirow{4}{*}{0.337} \\
\hline $20-30$ & $\begin{array}{c}60 \\
(67.4 \%)\end{array}$ & $\begin{array}{c}29 \\
(32.6 \%)\end{array}$ & \\
\hline $30-40$ & $\begin{array}{c}14 \\
(66.7 \%)\end{array}$ & $\begin{array}{c}7 \\
(33.3 \%)\end{array}$ & \\
\hline $\begin{array}{l}\text { More than } \\
\quad 40\end{array}$ & $\begin{array}{c}19 \\
(86.4 \%)\end{array}$ & $\begin{array}{c}3 \\
(13.6 \%)\end{array}$ & \\
\hline \multicolumn{4}{|l|}{ Gender } \\
\hline Male & $\begin{array}{c}225 \\
(64.1 \%)\end{array}$ & $\begin{array}{c}126 \\
(35.9 \%)\end{array}$ & \multirow{2}{*}{$\begin{array}{l}0.000 \\
F\end{array}$} \\
\hline Female & $\begin{array}{c}164 \\
(85.0 \%)\end{array}$ & $\begin{array}{c}29 \\
(15.0 \%)\end{array}$ & \\
\hline \multicolumn{4}{|l|}{ City } \\
\hline Makkah & $\begin{array}{c}202 \\
(76.5 \%)\end{array}$ & $\begin{array}{c}62 \\
(23.5 \%)\end{array}$ & \multirow{5}{*}{0.022} \\
\hline Jeddah & $\begin{array}{c}145 \\
(69.7 \%)\end{array}$ & $\begin{array}{c}63 \\
(30.3 \%)\end{array}$ & \\
\hline Taif & $\begin{array}{c}40 \\
(58.8 \%)\end{array}$ & $\begin{array}{c}28 \\
(41.2 \%)\end{array}$ & \\
\hline Qunfuthah & $\begin{array}{c}1 \\
(33.3 \%)\end{array}$ & $\begin{array}{c}2 \\
(66.7 \%)\end{array}$ & \\
\hline Leith & $\begin{array}{c}1 \\
(100.0 \%)\end{array}$ & $\begin{array}{c}0 \\
(0.0 \%)\end{array}$ & \\
\hline \multicolumn{4}{|l|}{ Education } \\
\hline Primary & $\begin{array}{c}2 \\
(66.7 \%)\end{array}$ & $\begin{array}{c}1 \\
(33.3 \%)\end{array}$ & \multirow{3}{*}{0.717} \\
\hline Secondary & & & \\
\hline high & $\begin{array}{c}69 \\
(68.3 \%)\end{array}$ & $\begin{array}{c}32 \\
(31.7 \%)\end{array}$ & \\
\hline
\end{tabular}




\begin{tabular}{|c|c|c|c|}
\hline University & $\begin{array}{c}318 \\
(72.3 \%)\end{array}$ & $\begin{array}{c}122 \\
(27.7 \%)\end{array}$ & \\
\hline \multicolumn{4}{|l|}{ Income } \\
\hline $\begin{array}{c}\text { Less than } \\
1 \mathrm{~K}\end{array}$ & $\begin{array}{c}258 \\
(72.9 \%)\end{array}$ & $\begin{array}{c}96 \\
(27.1 \%)\end{array}$ & \multirow{6}{*}{0.444} \\
\hline $1 K-3 K$ & $\begin{array}{c}40 \\
(61.5 \%)\end{array}$ & $\begin{array}{c}25 \\
(38.5 \%)\end{array}$ & \\
\hline $3 K-5 K$ & $\begin{array}{c}28 \\
(75.7 \%)\end{array}$ & $\begin{array}{c}9 \\
(24.3 \%)\end{array}$ & \\
\hline $5 K-10 K$ & $\begin{array}{c}29 \\
(69.0 \%)\end{array}$ & $\begin{array}{c}13 \\
(31.0 \%)\end{array}$ & \\
\hline $10 \mathrm{~K}-20 \mathrm{~K}$ & $\begin{array}{c}24 \\
(70.6 \%)\end{array}$ & $\begin{array}{c}10 \\
(29.4 \%)\end{array}$ & \\
\hline $\begin{array}{c}\text { More than } \\
20 \mathrm{~K}\end{array}$ & $\begin{array}{c}10 \\
(83.3 \%)\end{array}$ & $\begin{array}{c}2 \\
(16.7 \%)\end{array}$ & \\
\hline
\end{tabular}

\section{Discussion}

This study aimed to assess the community's level of knowledge, self-reported practice, and attitude regarding self-ear cleaning. $80 \%$ of participants showed poor knowledge regarding self-ear cleaning, as only $8.1 \%$ appreciated the harmful effect of this habit, and $60.5 \%$ will not consult a doctor if they experienced hearing difficulties. This decreased level of awareness is a widespread issue. Different studies were conducted internationally to assess the communities' information and had similar results $[6,8]$. In this study, most of the participants practiced self-ear cleaning. Similarly, a study done in Nigeria found that $93.4 \%$ of educated young individuals practiced this habit, regardless of age, educational level, or income [5,12]. High prevalence was also noted in studies conducted in Saudi Arabia (75\%) [12], Nigeria (80\%) [6], Malaysia (92\%) [13] and Bhutan $(92.15 \%)$ [14]. Healthcare workers also did not have adequate knowledge and most of them perform matching practice $[15,16]$. It is as high as $94 \%$ in a study by Oladeji et al. that was conducted on health workers in a tertiary hospital, which raised concerns considering their role in public awareness [1]. Uniform high rates in all studies suggest high prevalence across communities. The most common reasons for performing self-ear cleaning were to remove dirt and to improve ear hygiene. Alshehri et al. described similar beliefs of what made people practice this habit [17]. Amutta et al. and Lee et al. reported that it is mainly performed to clean the wax as it is considered dirt $[6,13]$. Ear itchiness was the dominant reason of ear cleaning in a study done by Afolabi et al. on the African population [18]. Similarly, in other studies, the majority clean both ears once a week with cotton buds as the preferred tool $[8,13,15,17,19]$. Even though it can cause further cerumen accumulation [15], less preferred tools were tissues, feathers, and keys. Random attempts to clean the ears, especially if it was done with no direct visualization, or using foreign tools to clean the ears and remove wax, are the main causes of trauma and otitis externa [19]. About half of the participants did not complain of symptoms after cleaning their ears, and most did not have any complications. In another study done on a group of university students, a lower percentage $(25.2 \%)$ of students reported no complaints of any related symptoms after ear cleaning [8]. In this study $18 \%$ suffered from ear itchiness, pain, discharges, and fullness ( $8 \%, 4.4 \%$ and $2.3 \%$ respectively). Reported injuries were external auditory canal abrasion as the commonest followed by tympanic membrane perforation and impaction of cerumen [15]. The association between demographic data and level of knowledge were assessed. A significant association was found between gender and level of knowledge, and male participants showed poor awareness compared to females with $\mathrm{p}$-value $<0.014$. Similar results were obtained from other studies conducted by Aldawsari et al. and Alharbi et al. on the Saudi population [20,21]. A significant relation between gender and practicing self-ear cleaning was also detected as more females were involved in this habit. There was no significant relationship between age, geographic distribution, educational level and income with the level of knowledge regarding this topic. The ear protects and cleans itself by producing cerumen. The outward migration of the epithelium and trapping the dirt by the hair that lines the skin of the ear's outer part all play a role in maintaining the ears clean [18]. Kravitz et al. and Tunming et al. described the ignorant attitude of the communities to the offered bits of advice regarding the harmful consequences of inserting foreign objects into the ear canal $[22,23]$. The mistaken perception of the beneficial role of self-ear cleaning might be a factor encouraging this habit. Nevertheless, it is not the only influencing factor since $74.2 \%$ of the people who believed otherwise were performing self-ear cleaning [5]. This factor can be modified by raising public awareness.

\section{Conclusion}

Self-ear cleaning is a widespread practice, and most respondents showed a lack of knowledge regarding 
ear-cleansing mechanisms. To rectify the erroneous views, more public health education is needed to dissuade people from practicing self-ear cleaning and teach them about the function of cerumen and problems associated with self-ear cleaning. This shows the important of public education to avoid complications that can be caused by self-ear cleaning. We recommend doing public campaigns teaching the general population to avoid self-ear cleaning and encourage them to visit doctors when having ear symptoms.

\section{Conflict of Interest}

The authors declare that there is no conflict of interest regarding the publication of this article.

\section{Funding}

This research did not receive any specific grant from funding agencies in the public, commercial, or not-forprofit sectors.

\section{References}

1. Oladeji SM, Babatunde OT, Babatunde LB, Sogebi OA. Knowledge of Cerumen and Effect of Ear SelfCleaning Among Health Workers in a Tertiary Hospital. J West African Coll Surg. 2015;5(2):117-33. PMID: 27830126

2. Burton MJ, Doree C. Ear drops for the removal of ear wax. Cochrane Database Syst Rev. 2018;2(7). https://doi.org//10.1002/14651858.CD012171.pub2

3. Shokry E, Marques JG, Ragazzo PC, Pereira NZ, Filho NRA. Earwax as an alternative specimen for forensic analysis. Forensic Toxicol. 2017;35(2):34858. https://doi.org/10.1007/s11419-017-0363-z

4. Alvord L, Farmer B. Anatomy and orientation of the human external ear. J Am Acad Audiol. 1997;8(6):383-90. PMID: 9433684

5. Olaosun A. Self-ear-cleaning among educated young adults in Nigeria. J Fam Med Prim Care. 2014; 3(1):17. https://doi.org/10.4103/2249-4863.130262

6. Amutta SB, Yunusa MA, Iseh KR, Obembe A, Egili E, Aliyu D, et al. Sociodemographic Characteristics and Prevalence of Self Ear Cleaning in Sokoto Metropolis. Int J Otolaryngol Head \&amp. Neck Surg. 2013;02(06):276-9.

http://dx.doi.org/10.4314/eajph.v6i1.45743

7. Schwartz SR, Magit AE, Rosenfeld RM, Ballachanda BB, Hackell JM, Krouse HJ, et al. Clinical Practice Guideline (Update). Otolaryngol Head Neck Surg (United States). 2017;156(1_suppl):S1-29. https://doi.org/10.1177\%2F0194599816671491

8. Khan NB, Thaver S, Govender SM. Self-ear cleaning practices and the associated risk of ear injuries and ear-related symptoms in a group of university students. J Public Health Africa. 2017;8(2):149-54.

https://dx.doi.org/10.4081\%2Fjphia.2017.555

9. Adegbiji, W.A., Olajide, T.G. and Nwawolo CC. Patterns of Self Ear Cleaning Among Otorhinolaryngology Patients in Developing Country. Asian J Sci Technoogy. 2018;09(04):7892-6. ISSN 0976-3376

10. Jabor M, Amedee R. Cerumen impaction. J La State Med Soc. 1997;149(10):358-62. PMID: 9347631.

11. Guest JF, Greener MJ, Robinson AC, Smith AF. Impacted cerumen: Composition, production, epidemiology and management. QJM - Mon J Assoc Physicians.2004;97(8):477-88.

https://doi.org/10.1093/qjmed/hch082

12. Alruwaili H, Dar U, Alshammari A, Alshaalan S, Alrubayyi S, Aljabbab N. Knowledge and practices regarding ear hygiene among Saudi adolescents. Int J Med Dev Ctries. 2021;5(December 2020):224-8. https://dx.doi.org/10.24911/IJMDC.51-1606825984

13. Lee LM, Govindaraju R, Hon SK. Cotton bud and ear cleaning - A loose tip cotton bud. Med J Malaysia. 2005;60(1):85-8. PMID: 16250286

14. Adhikari TR, Jamtsho S. Prevalence of ear cleaning and its characteristic physical findings in patients visiting tertiary care center in Bhutan. Bhutan Heal J. 2018;4(1):42-5. https://doi.org/10.47811/bhj.55

15. Nimkur AAA and TL. Ear Care: Knowledge, Attitude and Practice Amongst Health Professionals At the Jos University Teaching Hospital. Dep Otorhinolaryngol Head Neck Surgery. Fac Med Sci Univ Jos. 2016;(January 2013):274-81. Corpus ID: 73789251

16. Lukolo LN, Kimera LC, Pilbee G. Self-Ear Cleaning Practices and the Associated Risks: A Systematic Review. Glob J Health Sci. 2021;13(5):44. https://doi.org/10.5539/gjhs.v13n5p44

17. Alshehri A, Asiri K, Alahmari M, Alwabel H, Alahmari Y, Mahmood S. Knowledge, attitudes, and practices of self-ear cleaning among medical and nonmedical students at King Khalid University. Abha Saudi Arabia. Int J Med Dev Ctries. 2020;4(April):960-7.

https://doi.org/10.24911/IJMDC.51-1584110722

18. Makino K, Amatsu M. Epithelial migration on the tympanic membrane and external canal. Arch Otorhinolaryngol. https://doi.org/10.1007/bf00457906
1986;243(1):39-42. 
19. Nussinovitch M, Rimon A, Volovitz B, Raveh E, Prais D, Amir J. Cotton-tip applicators as a leading cause of otitis externa. Int J Pediatr Otorhinolaryngol. 2004;68(4):433-5.

https://doi.org/10.1016/j.ijporl.2003.11.014

20. Aldawsari SA, Aldawsari AA, Aljthalin AA, Aldossari FM, Alhammad MA, Saud M, et al. Knowledge , Attitudes and Practices of Self-Ear Cleaning Among Medical Students . Majmaah University.Saudi Arabia. 2018;4(4). https://doi.org/10.24911/IJMDC.51-1584110722

21. Alharbi M, Almasri M, Aldayel A, Alkhonezan S. Parental Knowledge, Attitudes and Practices Towards Paediatric Ear Infections in Riyadh, Saudi Arabia. Clin Basic Reasearch. 2019;19(2):114-21. https://dx.doi.org/10.18295\%2Fsqumj.2019.19.02.00 6

22. Kravitz H, Arthur I, David O, Harold I. The Cotton-Tipped Swab: A Major Cause of Ear Injury and Hearing Loss. Clin Pediatr (Phila). 1974;13(11):965-70.

https://doi.org/10.1177/000992287401301109

23. Tunming P, Tumrongarnuntasakul K, Suphagalin N, Suggsangawong P. Knowledge and Behavior of Khon Kaen University Student for Ear Picking. Srinagarind Med J. 2006;21(1):8-2. 